\title{
Evaluation of the effects of rehabilitation after surgery using the Ravitch and Nuss methods: a case study
}

\author{
Monika Bal-Bocheńskaํㅜ, Wojciech Kądziołka², Adam Rzechonek ${ }^{3}$ \\ ${ }^{1}$ Subcarpatian Center for Pulmonary Diseases in Rzeszów, Rzeszów University, School of Medicine, \\ Rzeszów, Poland \\ 2Subcarpatian Center for Pulmonary Diseases in Rzeszów, Poland \\ ${ }^{3}$ Lower Silesian Lung Disease Centre in Wroclaw, Poland
}

Kardiochirurgia i Torakochirurgia Polska 2016; 13 (1): 72-77

\begin{abstract}
Rehabilitation may be helpful in the prevention of complications associated with the treatment of patients with pectus excavatum who are subjected to surgery using the Ravitch and Nuss methods. This paper presents the case of a patient who underwent successful physical rehabilitation after 8 weeks from the surgery using the combined method. As part of the Nuss procedure, two plates were implanted to form a scaffolding for the patient's chest, which had previously been corrected with the Ravitch method. The plates were to be removed after 24 months of treatment. After the procedure, in spite of the favorable cosmetic effect of the repair, there was a significant decrease in the spirometric values and physical fitness of the patient. He underwent an individual physiotherapy program, which lasted four weeks. The streamlining of the respiratory system has significantly improved the spirometric values and raised the overall performance of the patient's organism.

Key words: rehabilitation, Ravitch method, Nuss method, spirometry.
\end{abstract}

\section{Introduction}

In normal anatomy of the chest, the sternum and the whole anterior chest wall form the most anterior part of the body. Pectus excavatum is a condition in which the lower part of the sternum and the adjoining rib segments are sunken into the chest [1-3]. The displacement of the sternum and ribs in the direction of the vertebral column reduces the anteroposterior dimension of the chest; as a result, the vital capacity of the lungs is reduced, which contributes to the development of disorders of the circulatory and respiratory systems. These changes are a frequent cause of recurrent bronchitis and pneumonia, dyspnea, and fatigability. The etiology of this deformation is not fully understood. The condition may be acquired as a result of inflammatory processes and rachitis; its congenital form (5\%) may be as-

\section{Streszczenie}

Rehabilitacja może być pomocna w zapobieganiu powikłaniom związanym z wadą i leczeniem pacjentów z klatką piersiową szewską (pectus excavatum), u których wykonano zabieg operacyjny metodą Ravitcha i Nussa. W pracy przedstawiono przypadek pacjenta, u którego z powodzeniem zastosowano rehabilitację ruchową po 8 tygodniach po zabiegu torakochirurgicznym metodą złożoną. Polegała ona na wprowadzeniu w uprzednio skorygowaną klatkę piersiową metodą Ravitcha dwóch płytek tworzących rodzaj rusztowania według metody Nussa. Implanty były niezbędne do korekcji nawrotu deformacji klatki piersiowej. Po zabiegu - mimo korzystnego efektu wizualnego - stwierdzono znaczne obniżenie wartości spirometrycznych i wydolności fizycznej pacjenta. Operowany pacjent został poddany indywidualnemu programowi fizjoterapii, który trwał 4 tygodnie.

Słowa kluczowe: rehabilitacja, metoda Ravitcha, metoda Nussa, spirometria.

sociated with impairments in the development of the diaphragm or disproportionate growth of the costal cartilages. There is no evidence indicating that rehabilitation can slow the development of the deformation or reverse it; the only effective method of treatment is surgery.

The aim of the study is to present the case in which pectus excavatum recurred and was treated with two methods of surgical repair; good results of respiratory rehabilitation were achieved, which significantly contributed to the improvement of the patient's general and respiratory fitness.

\section{Case report}

In 2000, at the age of 7, the patient underwent repair of the chest deformity using the Ravitch method at the Lower Silesian Center for Lung Diseases in Wrocław. The cosmetic and 
functional effect of the procedure was good. However, during the period of the boy's quickened growth between the ages of 15 and 17, the deformation began to recur, and the chest's anatomy deteriorated systematically. The patient experienced dyspnea and chest pain during intense cough. After he turned 20, examinations showed that the lower part of his sternum, sunken inwards, was displaced dangerously close to the spine (Fig. 1). On 15 August 2014, the patient underwent a redo procedure in order to repair the recurrent chest deformity, which had first been repaired using the Ravitch method (Fig. 2).

The surgery was performed using a modified Nuss procedure. The whole scar left after the previous procedure was excised. As the operators dissected the hard fibrous tissue, the anterior surface of the mesosternum was uncovered. Next, the medial segments of the $3^{\text {rd }}, 4^{\text {th }}$, and $5^{\text {th }}$ intercostal spaces were uncovered bilaterally. Two canals were formed under the sternum using both dull, and sharp dissection. The dissection was performed under visual control using

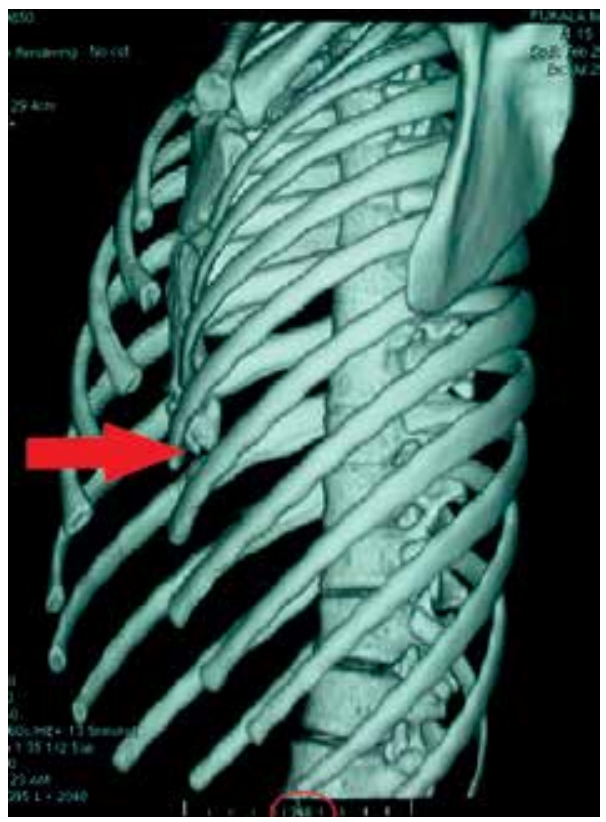

Fig. 1. Section through the patient's thorax: pectus excavatum

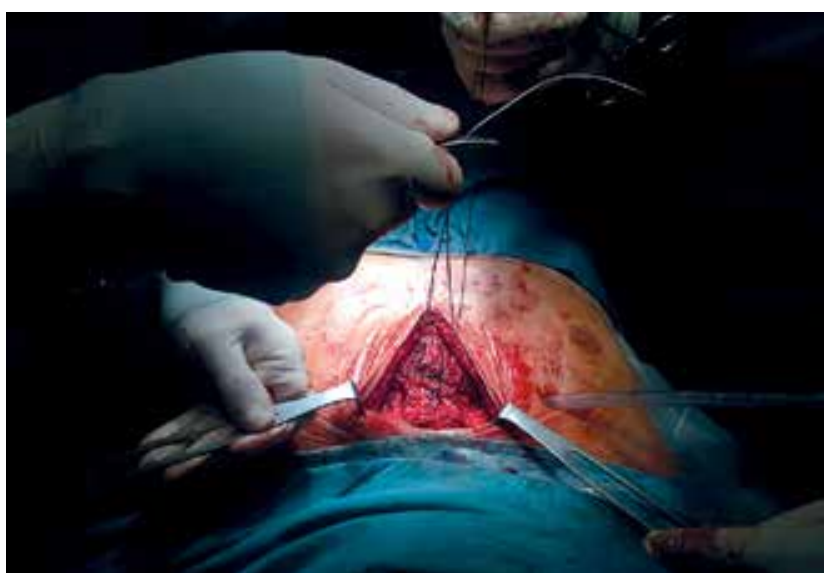

Fig. 3. The sternum was raised on two thick sutures a thoracoscopic camera introduced into the intercostal spaces at the axillary line. Subsequently, the sternum was raised on two thick sutures (Fig. 3). Skin on both sides of the chest was incised between the anterior and middle axillary lines, at the level of the $4^{\text {th }}$ intercostal spaces. Bilaterally, two tunnels were formed under the muscles of the chest wall, at the level of the $3^{\text {rd }}$ and $5^{\text {th }}$ intercostal spaces (Fig. 4).

During the dissection, the right internal thoracic artery was injured. The bleeding was stopped with sutures, and the bleeding site was monitored with a thoracoscope. Two implants were modelled (32 and $36 \mathrm{~cm}$ in length) and placed under the sternum. Concurrently, both implants were twisted under the mesosternum. At the level of the $3^{\text {rd }}$ intercostal space, a lateral fissure was observed in the mesosternum. Therefore, the forces had to be distributed onto two implants. After the implants were screwed into position, the cosmetic effect of the chest repair was very good. The implants were bilaterally sutured to the chest wall. Air was suctioned out

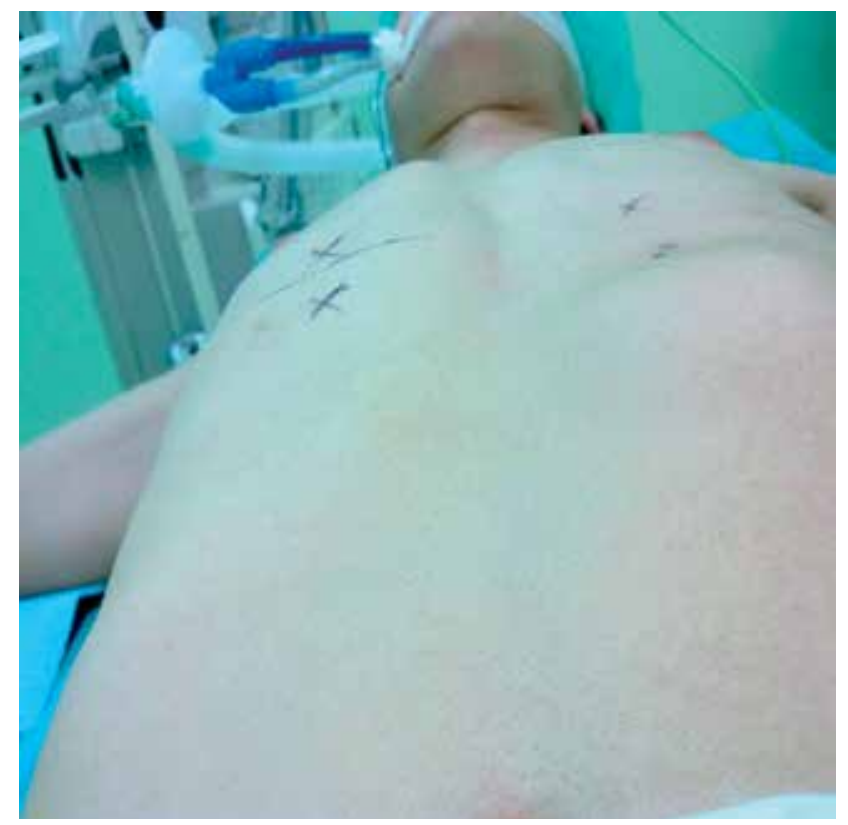

Fig. 2. The patient prepared for the surgery

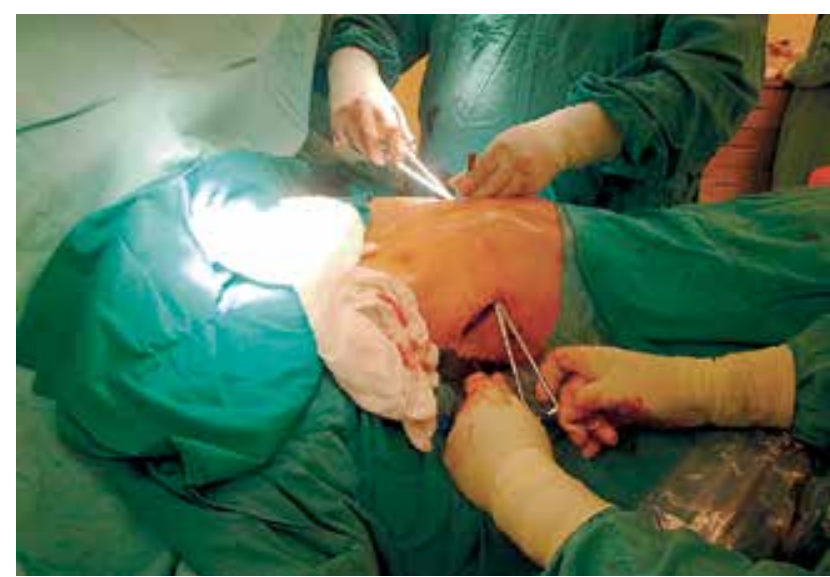

Fig. 4. Two implants were embedded under the sternum 
of the pleural cavity. A Redon drain was placed on the floor of the sternal wound; the wound was closed with a layered suture and covered with sterile dressing. The postoperative course was uneventful. Control X-ray examinations demonstrated normal lung expansion (Fig. 5). The patient was discharged from the Lower Silesian Center for Lung Diseases in Wrocław in good general condition; he was advised to report to his local surgery clinic for a postoperative control examination and suture removal. The patient was to report back to the Center after 2-3 years in order to plan the second stage of the procedure - the removal of the implants.

After the thoracic procedure, the patient received postoperative advice. During the first 3 postoperative months, he was to avoid bending or twisting the torso. He was also prohibited from carrying weights and discouraged from participating in contact sports. The patient adhered to the postoperative recommendations; over the next 8 weeks, he limited physical activity to the minimum and tried to make all upper extremity movements in symmetry. During the same year, on 16 October, the 21-year-old patient was admitted to the physiotherapy unit of the Subcarpathian Center for Pulmonary Diseases in Rzeszów. Ultrasonographic examination of the patient's chest revealed no postoperative complications; however, when spirometry was performed, the results were unsatisfactory, which was in line with the information obtained from the patient during an interview. He reported fatigability even during little exertion and significantly reduced strength.

According to the results of the spirometric examination performed before the start of the rehabilitation process, his forced vital capacity (FVC) was limited to $48 \%$, forced expiratory volume in 1 second $\left(\mathrm{FEV}_{1}\right)$ was reduced to $55 \%$, and the $\mathrm{FEV}_{1} / \mathrm{FVC}$ ratio amounted to $116 \%$. The patient's peak expiratory flow (PEF) was 65\%. Additionally, a Voldyne 5000 device was used to measure his inspiratory volume. According to the patient characteristics (age, height, sex), the result should fall within the range of $3600 \mathrm{ml} / \mathrm{min}$ on the nomogram. However, the measured inspiratory volume was $2300 \mathrm{ml} / \mathrm{min}$.

Further physiotherapeutic examination demonstrated that the patient's head jutted forward, his shoulders slouched and jutted forward, and the shoulder blades were

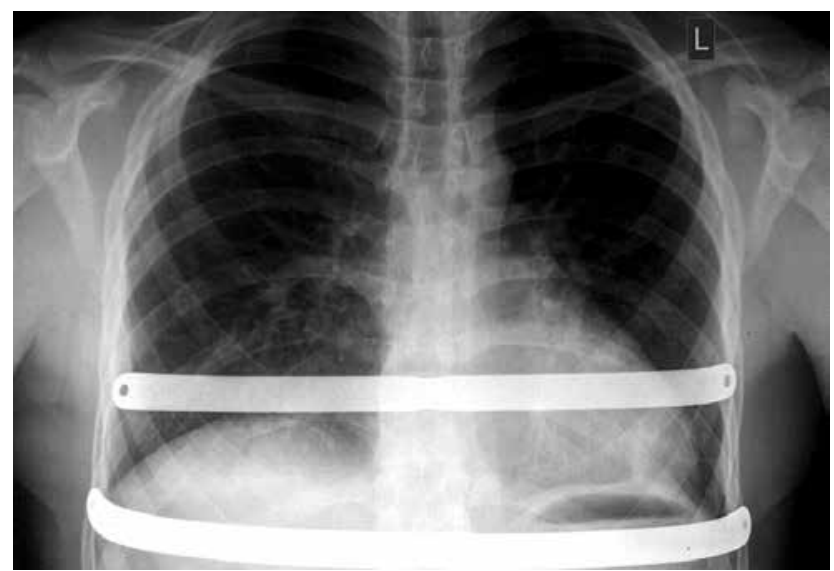

Fig. 5. Thoracic X-ray of the 21-year-old patient after Ravitch and Nuss procedures protruding. Moreover, the anteroposterior dimension of the flattened chest was reduced, and the shoulder girdle was contractured. Additionally, the stretching of the dorsal muscles (the trapezius, rhomboid, latissimus dorsi) contributed to the development of thoracic hyperkyphosis, a defect also known as round back. The chest muscles were excessively tense, while the abdominal muscles demonstrated excessive flaccidity, which led to the impairment of breathing (Fig. 6).

The patient was offered a personalized rehabilitation program aimed to improve the fitness of his circulatory and respiratory systems and to correct his posture.

Three fundamental aspects were addressed by the therapeutic proceedings:

- morphological: to eliminate muscle dystonia and strengthen the muscular corset,

- physiological: to teach the patient to adopt the correct posture and form the habit of maintaining it,

- environmental: to ensure that the patient's life conditions are conducive to eliminating the defect.

The occurrence of muscle contractures limited the mobility of the patient's joints and precluded him from assuming the proper posture. The first step to eliminate the dystonia was to stretch the muscles and restore full joint mobility. When stretching the muscles, the following rules were observed:

- during the initial stage of the stretching, the exercise consisted mostly in passive stretching,

- the direction of stretching movements addressed the functional structure of the muscles,

- when a muscle was stretched, moving one of its attachments further away, the other attachment site was stabilized.

Reducing the contractures of the thoracic muscles and the serratus anterior enabled the patient to assume

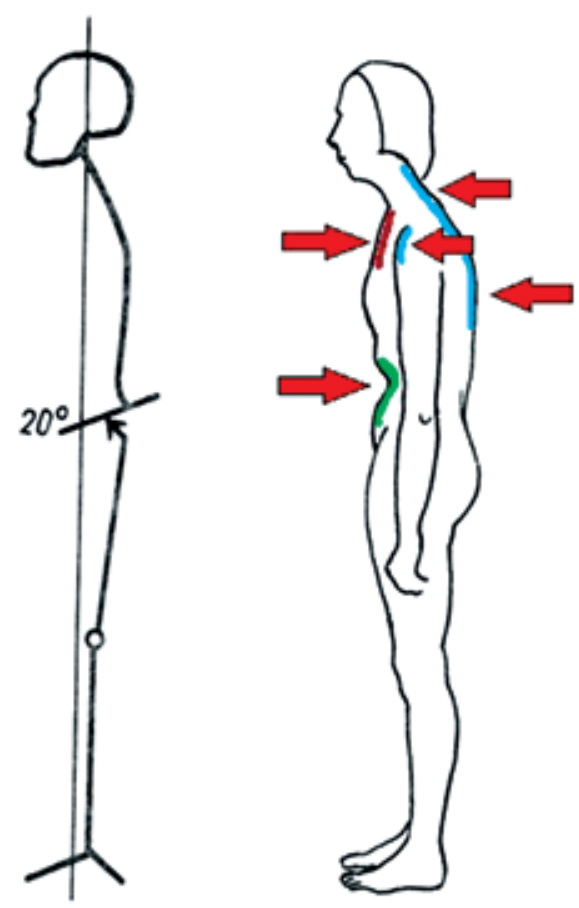

Fig. 6. Patient's position assumed in order to protect the surgical site 
the proper posture. Improving the posture began with partial/local corrections (adjusting the position of the head, moving back the shoulder girdle, reducing thoracic kyphosis, expanding the chest), which were later combined to achieve holistic/global correction. Initially, the exercises were limited to positions that freed the vertebral column from axial compression (with the patient lying down or kneeling on his hands and knees); gradually, sitting and standing exercises were introduced as well. This allowed the patient to control his posture first by adhering to a stable surface (floor, walls), then by visual control using a mirror, and finally using proprioception.

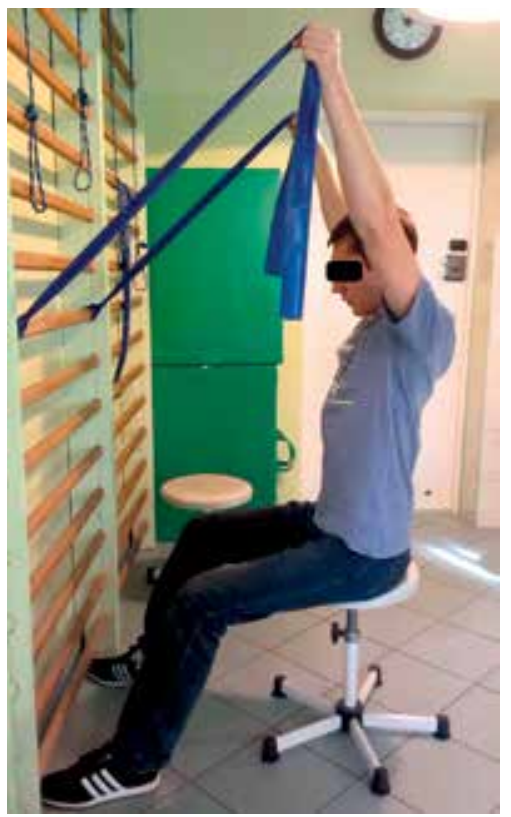

Fig. 7. Kinesitherapy with Thera-band resistance bands

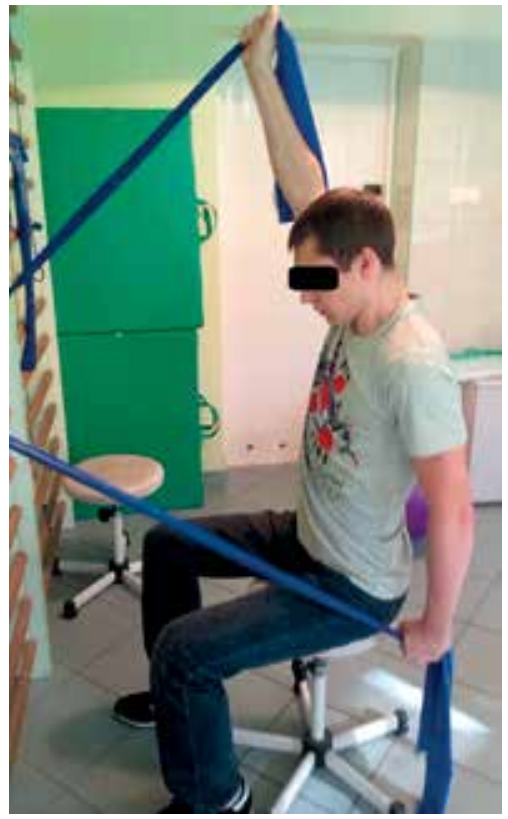

Fig. 8. Breathing exercises aimed at increasing thoracic mobility during thoracic and diaphragmatic breathing
To strengthen the weakened muscles, exercises in the trained corrected position were employed. The corrected position was maintained throughout the duration of the exercise, and the use of resistance (Thera-Band resistance bands) did not result in the loss of correction (Fig. 7). The program included formative, strengthening, and stretching exercises. The next stage of postoperative rehabilitation consisted in respiratory kinesitherapy (Fig. 8). The aim of these exercises was for the patient to learn how to breathe by increasing the vital capacity of the lungs (Fig. 9), to strengthen his respiratory muscles, and to increase the mobility of the chest during thoracic and diaphragmatic breathing, especially during inspiration (raising the ribs up and forward). Systematic exercise and ergometer training allowed the patient to develop the habit of assuming the proper posture during exercises. In terms of morphology, the mobility of the shoulder joints was increased, as was the strength of the dorsal, abdominal, and other postural muscles.

After the conclusion of the rehabilitation program, conducted at the Subcarpathian Center for Pulmonary Diseases in Rzeszów and lasting 4 weeks, spirometry was repeated. FVC amounted to $75 \%$, indicating an increase of $27 \%$. $\mathrm{FEV}_{1}$ was $77 \%$ (an increase of $22 \%$ ), while the $\mathrm{FEV}_{1} / \mathrm{FVC}$ ratio amounted to $103 \%$ (a decrease of $13 \%$ ). The patient's PEF after the rehabilitation increased by $14 \%$ (Fig. 10). Additionally, a Voldyne 5000 device was used to measure his inspiratory volume. The result, $3150 \mathrm{ml} / \mathrm{min}$, indicated an improvement of $850 \mathrm{ml} / \mathrm{min}$.

\section{Discussion}

Surgical treatment for pectus excavatum is a complex process requiring the cooperation of a medical team. The introduction of a new complex surgical method increased interest in the treatment, primarily due to cosmetic considerations and the visual effect after the procedure [4]. According to scientific reports, $81.4 \%$ of patients report for the procedure due to cosmetic reasons and low self-acceptance [5]. Despite the pain associated with the presence of the implants, persisting for up to several months, the patients view the impact of the procedure on their quality of life as favorable, as demonstrated in a study by Krasopou-

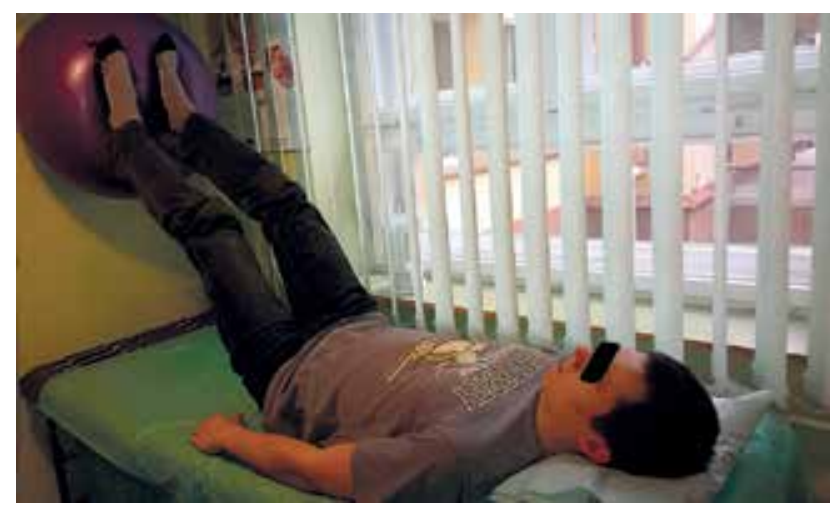

Fig. 9. Breathing and strengthening exercises in a closed system 
Flow-Volume

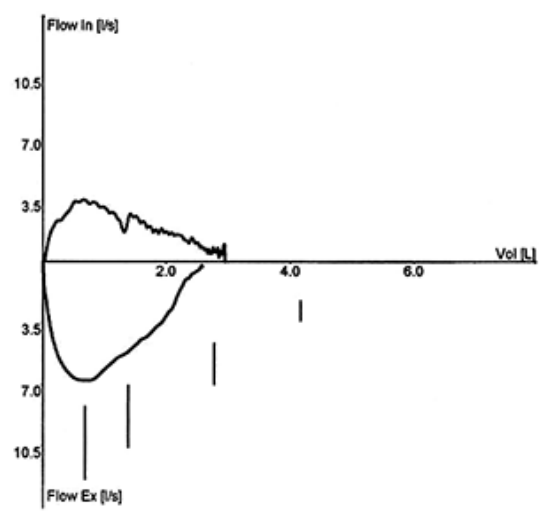

\begin{tabular}{|c|c|c|c|c|c|c|}
\hline Parameter & & Normal & Measured & Percent & SR & \multirow{7}{*}{\begin{tabular}{r}
\multicolumn{1}{c}{22} \\
2 \\
11 \\
1 \\
1
\end{tabular}} \\
\hline FEV 0.5 & \multirow{25}{*}{ 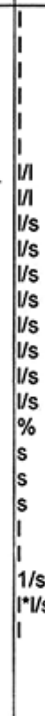 } & 3.21 & 2.55 & 79.4 & -0.76 & \\
\hline FEV 1 & & 4.65 & 3.60 & 77.3 & -2.08 & \\
\hline FEV 2 & & 5.77 & 4.10 & 71.0 & -1.23 & \\
\hline FEV 6 & & 5.55 & & & -9.10 & \\
\hline FVC & & 5.55 & 4.20 & 75.6 & -2.22 & \\
\hline FIVC & & 5.55 & 4.48 & 80.7 & -1.76 & \\
\hline FEV1/FVC & & 0.83 & 0.86 & 103.6 & 0.41 & 65 \\
\hline FEV1/FIVC & & 0.83 & 0.80 & 97.1 & -0.34 & 36 \\
\hline PEF & & 10.31 & 8.18 & 79.3 & -1.76 & 4 \\
\hline MEF 75 & & 8.80 & 6.01 & $\overline{68.3}$ & -1.63 & 5 \\
\hline MEF 50 & & 5.81 & 3.80 & 65.4 & -1.52 & 6 \\
\hline MEF 25 & & 2.79 & 2.20 & 78.9 & -0.75 & 22 \\
\hline MEF $25 / 75$ & & 5.18 & 3.70 & 71.4 & -1.42 & \\
\hline MEF $75 / 85$ & & & 6.56 & & & \\
\hline PIF & & 9.55 & 4.17 & 43.6 & & \\
\hline MIF 50 & & 8.62 & 3.45 & 40.0 & & \\
\hline MEF50\%FVC & & 104.68 & 90.55 & 86.5 & & \\
\hline & & 0.56 & 0.53 & 95.0 & & \\
\hline $\begin{array}{l}\text { TPEF } \\
\text { FET }\end{array}$ & & & $\begin{array}{l}0.05 \\
6.03\end{array}$ & & & \\
\hline $\begin{array}{l}\text { FEI } \\
\text { VPEF }\end{array}$ & & & 0.38 & & & \\
\hline VPIF & & & 0.68 & & & \\
\hline TC 25/50 & & & 1.53 & & & \\
\hline $\begin{array}{l}\mathrm{AEX} \\
\mathrm{EV}\end{array}$ & & $\begin{array}{r}32.25 \\
0.21\end{array}$ & $\begin{array}{r}16.28 \\
0.08\end{array}$ & $\begin{array}{l}50.5 \\
39.8\end{array}$ & & \\
\hline $\begin{array}{l}\text { FVC Q } \\
\text { FEV11 }\end{array}$ & & & $\begin{array}{l}\text { A } \\
B\end{array}$ & & & \\
\hline $\mathrm{FVQ}$ & & & B & & & \\
\hline
\end{tabular}

After

After
Flow-Volume

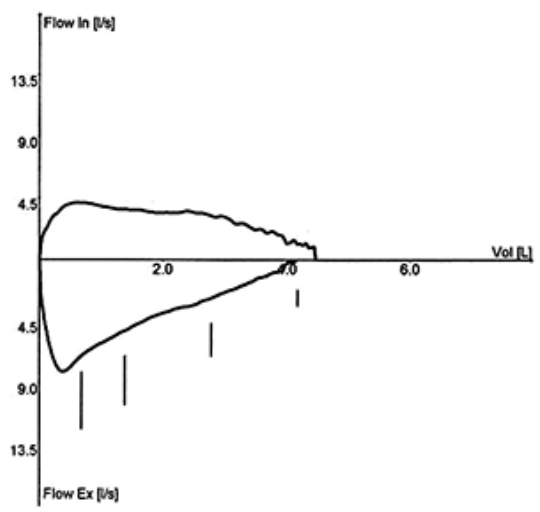

\begin{tabular}{|c|c|c|c|c|c|c|}
\hline Parameter & & Normal & Measured & Percent & $S R$ & $P$ \\
\hline FEV 0.5 & | & 3.34 & 2.28 & 68.3 & -1.22 & 11 \\
\hline FEV 1 & i & 4.65 & 2.57 & 55.3 & -4.08 & \\
\hline FEV 2 & & 5.94 & 2.64 & 44.4 & -2.43 & 1 \\
\hline FEV 6 & i & 5.37 & & & -3.84 & 1 \\
\hline FVC & & 5.55 & 2.67 & 48.0 & -4.73 & 1 \\
\hline FIVC & i & 5.55 & 2.97 & 53.5 & -4.24 & 1 \\
\hline FEV1/FVC & I/1 & 0.83 & 0.97 & 116.8 & 1.94 & 97 \\
\hline FEV1/FIVC & II & 0.83 & $\overline{0.87}$ & 104.9 & 0.57 & 71 \\
\hline PEF & i/s & 10.31 & 6.77 & 65.7 & -2.92 & 1 \\
\hline MEF 75 & i/s & $\frac{.80}{8.80}$ & 6.76 & 76.8 & -1.19 & 12 \\
\hline MEF 50 & i/s & 5.81 & 5.33 & 91.8 & -0.36 & 36 \\
\hline MEF 25 & $1 / \mathrm{s}$ & 2.79 & 3.42 & 122.8 & 0.81 & 79 \\
\hline MEF $25 / 75$ & is & 5.18 & 5.21 & 100.6 & 0.03 & 51 \\
\hline MEF $75 / 85$ & $1 / \mathrm{s}$ & & 7.02 & & & \\
\hline PIF & v/s & 9.63 & 3.52 & 36.5 & & \\
\hline MIF 50 & $1 / \mathrm{s}$ & & 2.54 & & & \\
\hline MEF50\%FVC & $\%$ & 104.68 & 200.11 & 191.2 & & \\
\hline $\begin{array}{l}\text { MTT } \\
\text { TPEF }\end{array}$ & s & 0.57 & 0.32 & 55.3 & & \\
\hline $\begin{array}{l}\text { FET } \\
\text { FET }\end{array}$ & s & & $\begin{array}{l}0.10 \\
4.51\end{array}$ & & & \\
\hline VPEF & i & & 0.68 & & & \\
\hline VPIF & & & 0.73 & & & \\
\hline TC 25/50 & $1 / \mathrm{s}$ & & 2.87 & & & \\
\hline & $\left.\right|^{*} \mid / \mathrm{s}$ & 32.25 & 11.33 & 35.1 & & \\
\hline $\begin{array}{l}\text { EV } \\
\text { FVC Q }\end{array}$ & & 0.15 & $\begin{array}{r}0.11 \\
A\end{array}$ & 76.0 & & \\
\hline FEV1 Q & & & $\hat{A}$ & & & \\
\hline
\end{tabular}

Before

Fig. 10. Selected spirometric values obtained before and after the rehabilitation process

los et al. [6]. Concurrently, the literature includes reports in which treatment with the combined methods was followed by reduced spirometric parameters and negative electrocardiography changes. A study by Dzielicki et al. demonstrated the occurrence of electrocardiographic changes in $60 \%$ of cases and spirometric changes in $38 \%$ of patients [7]. In his report, Adamczyk observed reduced VC and $\mathrm{FEV}_{1}$ [8]. Pectus excavatum is characterized by a reduction in the sagittal dimension of the chest, often accompanied by a displacement of the heart to the left, resulting in the occurrence of exercise tachycardia [9]. A study on the postoperative functioning of the lungs and the circulatory system after the surgical repair of pectus excavatum by Malek et al. demonstrated a statistically significant influence of the procedure on selected circulatory parameters and no such influence on spirometric values [10]. The literature lacks results concerning the effects of postoperative rehabilitation in patients undergoing combined Nuss and Ravitch procedures.
The rehabilitation process as such is often mentioned as conservative treatment before the surgery. There is no unequivocal evidence that rehabilitation has an impact on the reduction of the chest defect.

\section{Conclusions}

After the conclusion of the rehabilitation program, performed by a 21-year-old patient who had undergone surgery using the Ravitch and Nuss methods, the patient's spirometric parameters and general fitness improved significantly. Surgical treatment for pectus excavatum is a safe procedure that is successfully employed in young adults [11]. This patient group is characterized by stronger will to engage in everyday physical activity. However, after the surgery, these patients are faced with safety procedures limiting their ability to engage in physical work or participate in sports. Proceeding in accordance with the postoperative guidelines leads to a reduction in their fitness [12]. In turn, 
failing to adhere to the postoperative guidelines increases the risk of complications, of which the most frequent include: implant displacement, pneumothorax, and wound inflammation. The presented method of rehabilitation should find a wider application in comprehensive treatment provided for pectus excavatum. Apart from surgical repair, it should include pre- and postoperative rehabilitation and analgesic pharmacotherapy. The rehabilitation process should address the individual condition and fitness of the patient, obliging the physiotherapist to conduct a personalized program based on spirometric results [13]

\section{Disclosure}

Authors report no conflict of interest.

\section{References}

1. Park HJ, Lee SY, Lee CS, Youm W, Lee KR. The Nuss procedure for pectus excavatum: evolution of techniques and early results on 322 patients. Ann Thorac Surg 2004; 77: 289-295.

2. Molik KA, Engum SA, Rescorla FJ, West KW, Scherer LR, Grosfeld JL. Pectus excavatum repair: experience with standard and minimal invasive techniques. J Pediatr Surg 2001; 36: 324-328.

3. Hebra A, Swoveland B, Egbert M, Tagge EP, Georgeson K, Othersen HB Jr, Nuss D. Outcome analysis of minimally invasive repair of pectus excavatum: review of 251 cases. J Pediatr Surg 2000; 35: 252-257.
4. Nuss D, Kelly RE Jr, Croitoru DP, Katz ME. A 10-year review of a minimally invasive technique for the correction of pectus excavatum. J Pediatr Surg 1998; 33: 545-552.

5. Jo W, Choi Y, Sohn Y, Kim H, Hwang J, Cho S. Surgical treatment for pectus excavatum. J Korean Med Sci 2003; 18: 360-364.

6. Krasopoulos G, Dusmet M, Ladas G, Goldstraw P. Nuss procedure improves the quality of life in young male adults with pectus excavatum deformity. Eur J Cardiothorac Surg 2006; 29: 1-5.

7. Dzielicki J, Korlacki W, Janicka I, Dzielicka E. Difficulties and limitations in minimally invasive repair of pectus excavatum -6 years experiences with Nuss technique. Eur J Cardiothorac Surg 2006; 30: 801-804.

8. Adamczyk J, Pawlak K, Zieliński P, Dyszkiewicz W. Wczesne wyniki leczenia lejkowatej klatki piersiowej metodą Nussa. Kardiochir Torakochir Pol 2004; 2.

9. Aronson D, Bosgraaf R, Merz E, Steenwijk R, Aalderen W, Baren R. Lung function after the minimal invasive pectus excavatum repair (Nuss procedure). Word J Surg 2007; 31: 1518-1522.

10. Malek M, Berger D, Marelich W, Coburn J, Beck T, Housh T. Pulmonary function following surgical repair of pectus excavatum: a meta-analysis. Eur J Cardiothorac Surg 2006; 30: 637-643.

11. Woźniewski M, Kołodziej J. Rehabilitacja w chirurgii. Wydawnictwo Lekarskie PZWL, Warszawa 2010.

12. Bednarczuk G, Błeszyński J, Kaźmierska-Kowalewska K. Adaptowana aktywność fizyczna dla fizjoterapeutów. Wydawnictwo Lekarskie PZWL, Warszawa 2014

13. Pawlak K, Zieliński P, Gabryel P, Gałęcki B, Dyszkiewicz W. Early and late results of the Nuss operation for pectus excavatum - a single institution experience. Kardiochir Torakochir Pol 2013; 10: 364-368. 